\title{
Hubungan Antara Kandungan Pati Resisten dan Kualitas Tanak Beras Siger (Tiwul Modifikasi)
}

\section{The Relationship Between Resistant Starch Content and Cooking Quality of "Siger Rice" (Modified Tiwul)}

\section{Beni Hidayat*, M. Muslihudin, dan Syamsu Akmal}

Agricultural Technology Department, Politeknik Negeri Lampung

Email : beni_lpg@polinela.ac.id

\begin{abstract}
Resistant starch is a starch fraction that can not be hydrolyzed by digestive enzymes in the small intestine and classified as a prebiotic compound. Increasing the content of resistant starch to a certain amount in Siger Rice (modified tiwul) will decrease the cooking quality. The objective of this research was to study the relationship between resistant starch content and cooking quality of Siger Rice (eating quality, texture, and taste). The increase of resistant starch content in siger rice was done by the application of autoclaving-cooling cycling treatment, through steam stages, cooling to room temperature, followed by cooling at $4^{\circ} \mathrm{C}$ for 0 hours/control, 12 hours, 24 hours, 36 hours and 48 hours. The results showed that the increase of resistant starch content $\leq 10 \%(9.85 \%)$ will improve the quality characteristics of Siger Rice for all organoleptic scores, i.e., eating quality (7,15 to 8,2), texture (7.05 to 8.35), and flavor (6.95 to 8.15); on the contrary, the increase of resistant starch content more than $10 \%(14.25 \%)$ will decrease the cooking quality characteristics of Siger Rice for all organoleptic scores, i.e., eating quality (7.15 to 6.8), texture (7.05 to 6.6), and taste (6.95 to 6.4).
\end{abstract}

Keywords: siger rice, cooking quality, resistant starch, modified tiwul

Disubmit : 17 Oktober 2017, Diterima : 19 September 2017, Disetujui : 01 Januari 2018

\section{PENDAHULUAN}

Beras siger adalah produk beras analog singkong yang mengadopsi proses pembuatan tiwul tetapi dengan penampakan (bentuk yang lebih seragam, warna yang relatif lebih cerah) dan cita-rasa yang lebih baik (Hidayat, 2016). Produk Beras Siger ini pada dasarnya adalah produk tiwul instan yang telah dimodernisasi dan dimodifikasi proses pengolahannya. Berbeda dengan pengolahan tiwul secara tradisional, Beras Siger telah diproses secara mekanik menggunakan mesin perajang, mesin penggiling tepung, dan granulator. Salah satu kelebihan produk beras siger sebagai pangan pokok pengganti beras adalah memiliki karakteristik sebagai pangan fungsional yang tercermin dari tingginya kandungan pati resisten $(7,78 \%)$ dan rendahnya nilai indeks glikemik (Hidayat, dkk., 2016).

Menurut Raigond et al. (2015), kandungan pati resisten dapat digunakan untuk mengidentifikasi suatu pangan fungsional. Pati resisten merupakan fraksi pati yang tidak dapat terhidrolisis oleh enzim-enzim pencernaan pada usus halus dan diklasifikasikan sebagai senyawa prebiotik (Fuentes-Zaragoza et al., 2011). Menurut Lockyer and Nugent (2017), pati resisten memiliki efek fisiologis yang menguntungkan bagi kesehatan seperti pencegahan kanker kolon dan memiliki efek hipoglikemik (menurunkan kadar gula darah) 
dan efek hipokolesterolemik (menurunkan kadar kolesterol darah). Pangan dengan kandungan pati resisten tinggi dapat diklasifikasikan sebagai pangan prebiotik.

Menurut Hidayat, et al. (2017), pati resisten pada produk beras analog yang diproses dengan metode granulasi terbentuk akibat proses retrogradasi selama tahapan pemanasan-pendinginan. Pati resisten yang terbentuk selama proses pengolahan adalah pati resisten tipe 3/RS3 (Lockyer and Nugent, 2017). Upaya untuk meningkatkan karakteristik beras siger sebagai pangan fungsional dapat dilakukan melalui upaya meningkatkan intensitas tahapan pemanasan-pendinginan. Peningkatan kandungan pati resisten selama tahapan pemanasan-pendinginan juga telah dilaporkan oleh Ashwar et al. (2016); Dundar and Gocmen (2013); Zhao and Lin (2009).

Meskipun peningkatan kandungan pati resisten pada produk beras siger akan meningkatkan karakteristik produk sebagai pangan fungsional, tetapi hal ini diduga akan mempengaruhi karakteristik kualitas tanak produk, terutama akibat peningkatan derajat kristalinitas pati. Pati resisten tipe 3 (RS3) yang terbentuk akibat proses retrogradasi yang akan meningkatkan derajat kristalinitas produk (Haralampu, 2000; Alsaffar, 2011). Penelitian bertujuan mengkaji hubungan antara kandungan pati resisten dan kualitas tanak beras siger (kepulenan, tekstur, dan rasa).

\section{METODE PENELITIAN}

Penelitian dilakukan di Laboratorium Teknologi Hasil Pertanian Politeknik Negeri Lampung. Penelitian dilaksanakan pada Bulan April Hingga Oktober 2017. Bahan utama penelitian adalah ubi kayu varietas kasetsart yang diperoleh dari petani ubi kayu di Desa Margomulyo, Kecamatan Jati Agung, Kabupaten Lampung Selatan. Bahan-bahan kimia yang digunakan antara lain adalah pati standar (GR, Merck), maltosa (Sigma M5885), Dinitrosalicylic acid (DNS, Sigma D-0550), glukosa (Sigma G8270), enzim termamyl ( $\alpha$ amylase, Sigma A-4862), enzim pepsin (Sigma P-7000), enzim amyloglukosidase (Sigma A-9913), enzim pankreatin (Sigma P-1750) yang diperoleh dari PT Elo Karsa, Jakarta.

Alat utama yang digunakan pada pembuatan beras siger (tiwul modifikasi) antara lain adalah alat perajang, penggiling tife disk mill, ayakan tyler 60 mesh, granulator (pembentuk butiran beras), pengering kabinet, refrigerator; serta spektrofotometer UV-Vis untuk analisis kandungan pati resisten dan pati tercerna.

Tahapan Penelitian. Penelitian terdiri dari beberapa tahapan, yaitu (1) pembuatan Beras Siger (tiwul modifikasi), (2) penerapan perlakuan autoclaving-cooling cycling untuk meningkatkan kandungan pati resisten beras siger, (3) pengujian kandungan pati resisten, pati tercerna, dan total pati beras siger, dan (4) pengujian kualitas tanak beras siger. Pembuatan aneka varian Beras Siger. Beras Siger (tiwul modifikasi), diperoleh melalui tahapan pencucian ubi kayu, pengupasan, pengecilan ukuran (pengirisan) dalam bentuk chips dengan ketebalan $\pm 2 \mathrm{~cm}$, pengeringan, perendaman selama 48 jam, pengeringan tahap II, penggilingan hingga diperoleh tepung ubi kayu 60 mesh, pembentukan butiran dengan cara penambahan air sebanyak $45 \%$ dan pembentukan granul menggunakan granulator.

Penerapan perlakuan autoclaving-cooling cycling untuk meningkatkan kandungan pati resisten beras siger. Butiran Beras Siger selanjutnya dikukus selama 30 menit, pendinginan hingga suhu kamar, dan pendinginan pada suhu $4^{0} \mathrm{C}$ selama 0 jam (kontrol), 12 jam, 24 jam, 36 jam, dan 48 jam. Beras Siger (tiwul modifikasi) selanjutnya dikeringkan menggunakan pengering cabinet pada suhu $50^{\circ} \mathrm{C}$ selama 5 jam hingga diperoleh Beras Siger instan.

Pengujian kandungan pati resisten, pati tercerna, dan total pati Beras Siger. Pengujian kandungan pati resisten dan pati tercerna Beras Siger dilakukan dengan metode enzimatis (Englyst et al., 1992). Pengujian dilakukan dengan 6 kali ulangan dan data yang diperoleh disajikan dalam bentuk nilai rata-rata \pm standar deviasi (SD). Data yang diperoleh diolah menggunakan anova (sidik ragam) dilanjutkan dengan uji BNT pada tarap nyata 1 dan $5 \%$. 
Pengujian kualitas tanak beras siger. Pengujian kualitas tanak dilakukan dalam bentuk analisis sensoris tingkat kesukaan panelis terhadap parameter kepulenan, tekstur, dan rasa nasi dari beras siger berdasarkan metode Soekarto (1985) dan Champagne (1999). Penyiapan sampel dilakukan dengan cara penambahan air $1 / 2$ bagian Beras Siger lalu dimasak menggunakan rice cooker selama \pm 20 menit. Analisis organoleptik melibatkan 20 orang panelis dengan skala hedonik 1 (sangat tidak suka sekali) hingga 9 (sangat suka sekali). Data yang diperoleh dirata-ratakan dan disajikan dalam bentuk grafik jaring laba-laba (spider web).

\section{HASIL DAN PEMBAHASAN}

Kandungan Pati Resisten dan Pati Tercerna Beras Siger (Tiwul Modifikasi) pada Berbagai Lama

Pendinginan. Hasil pengujian pada Tabe 1 , menunjukkan bahwa lama pendinginan hingga 48 jam secara signifikan $(\mathrm{P} \leq 0,05)$ akan meningkatkan kandungan pati resisten beras siger dari $7.78 \%$ menjadi $16.13 \%$. Menurut Lockyer and Nugent (2017), pati resisten yang terbentuk akibat proses pengolahan adalah pati resisten tife 3 (RS3). Peningkatan kandungan pati resisten dengan semakin lama pendinginan berkaitan dengan semakin tingginya jumlah pati teretrogradasi yang terbentuk (Ashwar et al., 2016). Retrogradasi merupakan pembentukan kembali ikatan-ikatan hidrogen dari molekul-molekul amilosa membentuk struktur kristalin tife B (Raigond, et al. 2015). Molekul-molekul amilosa saling berikatan kembali dengan ikatan yang sangat kuat dan melengkapi struktur yang kuat di daerah amorf. Pada pati yang teretrogradasi, amilosa dan amilopektin dapat membentuk heliks ganda yang akan meningkatkan resistensi pati terhadap pencernaan enzimatis (Lyumugabe, et al., 2017). Peningkatan kandungan pati resisten akibat perlakuan pemanasan-pendinginan, juga dilaporkan oleh Ashwar et al. (2016); Dundar and Gocmen (2013); Zhao and Lin (2009).

Hasil pengujian pada Tabel 1, juga menunjukkan bahwa lama pendinginan hingga 48 jam secara signifikan $(\mathrm{P} \leq 0,05)$ akan menurunkan kandungan pati tercerna beras siger dari $60.34 \%$ menjadi $51.88 \%$. Penurunan kandungan pati tercerna ini sangat berkaitan erat dengan peningkatan kandungan pati resisten. Semakin tinggi kandungan pati resisten maka akan semakin rendah kandungan pati tercerna, dan sebaliknya. Menurut Ashwar et al. (2016), proses pemanasan-pendinginan akan menyebabkan terjadinya penyusunan kembali rantai amilosa dan amilopektin yang menyebabkan perubahan karakteristik fisikokimia dan daya cernanya. Penurunan daya cerna pati akibat terbentuknya pati resisten juga dilaporkan oleh (Hsu et al., 2015).

Tabel 1. Kandungan pati resisten, pati tercerna, dan total pati Beras Siger pada berbagai lama pendinginan (nilai rata-rata $\pm \mathrm{SD}$ ), \% berat kering

\begin{tabular}{ccc}
\hline Lama pendinginan (jam) & Pati resisten $(\%)$ & Pati tercerna $(\%)$ \\
\hline 0 (kontrol) & $7.78 \pm 0.10 \mathrm{e}$ & $60.34 \pm 0.58 \mathrm{a}$ \\
12 & $8.44 \pm 0.11 \mathrm{~d}$ & $59.62 \pm 1.15 \mathrm{a}$ \\
24 & $9.85 \pm 0.22 \mathrm{c}$ & $58.18 \pm 0.71 \mathrm{~b}$ \\
36 & $13.88 \pm 0.22 \mathrm{~b}$ & $54.23 \pm 0.67 \mathrm{c}$ \\
48 & $16.13 \pm 0.19 \mathrm{a}$ & $51.88 \pm 0.70 \mathrm{~d}$ \\
\hline
\end{tabular}

Keterangan : perlakuan yang diikuti dengan huruf yang sama tidak berbeda nyata $(P>0.05)$

Kualitas Tanak Beras Siger (Tiwul Modifikasi) Pada Berbagai Lama Pendinginan. Hasil penelitian pada Gambar 1, menunjukkan bahwa pendinginan hingga 24 jam akan meningkatkan skor kepulenan (7.15 menjadi 8.2), tekstur (7.05 menjadi 8.35), dan rasa (6.95 menjadi 8.15). Lama pendinginan mulai dari 24 jam hingga 48 jam akan menurunkan kembali skor kepulenan (8.2 menjadi 6.8), skor tekstur (8.35 menjadi 6.6), dan skor rasa (8.15 menjadi 6.4).

Peningkatan skor kepulenan, tekstur dan rasa hingga lama pendinginan 24 jam berkaitan dengan peningkatan tekstur krispy (renyah) akibat peningkatan kandungan pati resisten. Hal ini sesuai dengan 
pendapat Homayouni et al. (2014), yang menyatakan bahwa pati resisten akan meningkatkan kualitas tanak produk yang terutama berkaitan dengan peningkatan kerenyahan produk. Peningkatan kerenyahan produk akibat peningkatan kandungan pati resisten juga dilaporkan oleh Ashwar et al. (2016) dan Raigond et al. (2015).

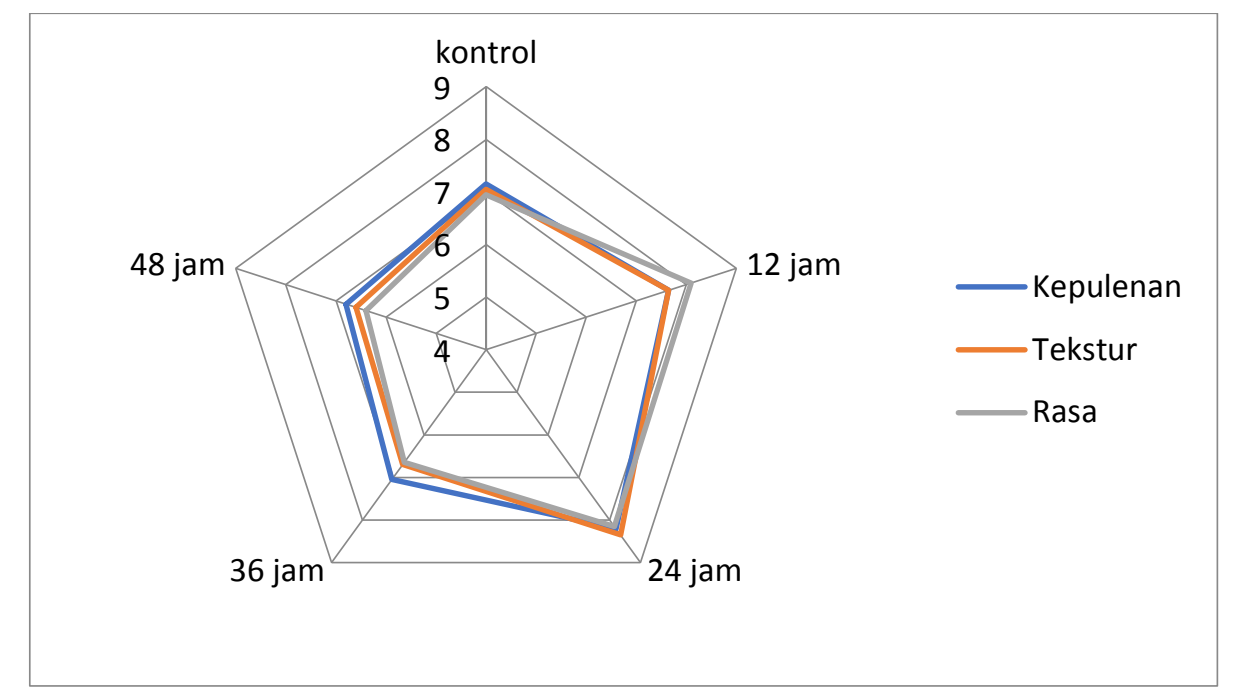

Keterangan skor: 9 (sangat suka sekali), 8 (sangat suka), 7 (suka), 6 (agak suka), 5 (netral), 4 (agak tidak suka)

Gambar 1. Kualitas tanak Beras Siger (kepulenan, tekstur, dan rasa) pada berbagai lama pendinginan (nilai rata-rata dari 20 panelis)

Penurunan kembali skor kepulenan, tekstur dan rasa setelah lama pendinginan 24 jam berkaitan dengan peningkatan kekerasan produk akibat peningkatan derajat kristalinitas pati. Peningkatan kandungan pati resisten akan menyebabkan peningkatan derajat kristalinitas (Alsaffar, 2011; Haralampu, 2000) dan indeks pengembangan (Ashwar et al., 2016; Lyumugabe et al., 2017). Peningkatan derajat kristalinitas dan penurunan indeks pengembangan akan menghasilkan produk beras siger dengan tekstur yang keras dan menurunkan skor persepsi konsumen terhadap tekstur dan kepulenan produk. Meskipun menurut Raigond $e t$ al., (2015), pati resisten relatif tidak berasa, tetapi persepsi panelis juga menunjukkan penurunan terhadap skor rasa produk .

Hubungan antara Kandungan Pati Resisten dan Kualitas Tanak Beras Siger (Tiwul Modifikasi). Hubungan antara kandungan pati resisten dan kualitas tanak beras siger (tiwul modifikasi), disajikan pada Tabel 2. Data hasil pengujian pada Tabel 2, menunjukkan bahwa hingga lama pendinginan 24 jam terdapat hubungan yang linier positif antara peningkatan kandungan pati resisten dan kualitas tanak beras siger. Peningkatan kandungan pati resisten hingga konsentrasi 9.85\% (<10\%) akan menghasilkan produk beras siger dengan karakteristik tanak (kepulenan, tekstur, rasa) yang makin disukai panelis. Peningkatan kualitas tanak sejalan dengan peningkatan kandungan pati resisten juga dinyatakan oleh Raigond et al., (2015) dan Homayouni et al. (2014).

Peningkatan kualitas tanak terutama berkaitan dengan peningkatan kekenyalan produk dengan semakin menurunnya nilai indeks pengembangan akibat semakin meningkatnya kandungan pati resisten (Asghar et al., 2012). Dibandingkan pati alami, pati resisten memiliki indeks pengembangan yang lebih rendah, sehingga tekstur produk tidak menjadi lengket. Hal yang serupa dilaporkan oleh Hidayat, dkk., (2016) pada pengembangan produk beras analog jagung yang ditambahkan dengan tapioka (pati ubi kayu). Penambahan tapioka hingga konsentrasi lebih dari 30\% akan menurunkan tingkat kesukaan panelis terhadap produk beras analog jagung yang dihasilkan karena tekstur nasi yang semakin lengket dan menyerupai bubur. 
Tabel 2. Hubungan antara kandungan pati resisten dan kualitas tanak Beras Siger (Tiwul Modifikasi) pada berbagai lama pendinginan

\begin{tabular}{ccccc}
\hline Lama pendinginan (jam) & Pati resisten $(\%)$ & \multicolumn{3}{c}{ Kualitas tanak } \\
\cline { 3 - 5 } & & Kepulenan & Tekstur & Rasa \\
\hline 0 (kontrol) & $7.78 \pm 0.10 \mathrm{e}$ & 7.15 & 7.05 & 6.95 \\
12 & $8.44 \pm 0.11 \mathrm{~d}$ & 7.65 & 7.65 & 8.10 \\
24 & $9.85 \pm 0.22 \mathrm{c}$ & 8.20 & 8.35 & 8.15 \\
36 & $13.88 \pm 0.22 \mathrm{~b}$ & 7.05 & 6.70 & 6.65 \\
48 & $16.13 \pm 0.19 \mathrm{a}$ & 6.80 & 6.60 & 6.40 \\
\hline
\end{tabular}

Keterangan skor : 9 (sangat suka sekali), 8 (sangat suka), 7 (suka), 6 (agak suka), 5 (netral), 4 (agak tidak suka)

Data hasil pengujian pada Tabel 2, juga menunjukkan bahwa setelah lama pendinginan 24 jam terdapat hubungan yang linier negatif antara peningkatan kandungan pati resisten dan kualitas tanak Beras Siger. Peningkatan kandungan pati resisten mulai dari konsentrasi 13.88\% (>10\%) akan menghasilkan produk Beras Siger dengan karakteristik tanak (kepulenan, tekstur, rasa) yang makin tidak disukai panelis. Hal ini menunjukkan bahwa konsentrasi optimal penambahan pati resisten adalah pada konsentrasi $\leq 10 \%$.

Penurunan persepsi kesukaan panelis pada konsentrasi pati resisten $>10 \%$, berkaitan dengan tekstur produk yang semakin keras. Peningkatan kekerasan produk beras siger (tiwul modifikasi) pada konsentrasi pati resisten $>10 \%$ tersebut berkaitan dengan sifat fisikokimia pati resisten yang akan menghasilkan tekstur produk yang semakin keras dengan indeks pengembangan yang rendah (Ashwar et al., 2016).

\section{KESIMPULAN}

Hasil penelitian menunjukkan bahwa peningkatan kandungan pati resisten hingga konsentrasi $\leq 10 \%$ (9.85\%) akan meningkatkan karakteristik kualitas tanak Beras Siger (tiwul modifikasi) untuk seluruh skor organoleptik yaitu kepulenan (7,15 menjadi 8.2), tekstur (7.05 menjadi 8.35), dan rasa (6.95 menjadi 8.15); sebaliknya peningkatan kandungan pati resisten pada konsentrasi lebih dari 10\% (13.88\%) akan menurunkan karakteristik kualitas tanak Beras Siger untuk seluruh skor organoleptik yaitu kepulenan (7.15 menjadi 6.8), tekstur (7.05 menjadi 6.6), dan rasa (6.95 menjadi 6.4).

\section{UCAPAN TERIMA KASIH}

Penulis mengucapkan terima kasih kepada Direktorat Riset dan Pengabdian Masyarakat, Kementerian Riset, Teknologi, dan Pendidikan Tinggi, atas pendanaan kegiatan ini melalui skim Iptek bagi Produk Unggulan Daerah (IbPUD) tahun 2017.

\section{DAFTAR PUSTAKA}

Alsaffar, A.A., 2011. Effect of food processing on the resistant starch content of cereals and cereal products a review. International Journal of Food Science and Technology, 3, pp.455-462.

Asghar, S. et al., 2012. Cooking and eating characteristics of Rice ( Oryza sativa L . ) - A review. Pakistan Journal of Food Sciences, 22(3), pp.128-132.

Ashwar, B.A. et al., 2016. Production of resistant starch from rice by dual autoclaving-retrogradation 1 treatment: 2 Invitro digestibility, thermal and structural characterization. Food Hydrocolloids, 56, pp.108-117.

Dundar, A.N. and \& Gocmen, D., 2013. Effects of autoclaving temperature and storing time on resistant starch formation and its functional and physicochemical properties. Carbohydrate Polymers, 97(2), pp.764771.

Fuentes-Zaragoza, E. et al., 2011. Resistant starch as prebiotic: A review. Starch/Staerke, 63(7), pp.406-415. 
Haralampu, S.., 2000. Resistant starch-a review of the physical properties and biological impact of RS3. Carbohydrate Polymers, 41(3), pp.285-292.

Hidayat, B., Akmal, S., Surfiana, dan Suhada, B., 2016. Beras Siger (Tiwul/Oyek yang Telah Dimodernisasi) sebagai Pangan Fungsional dengan Kandungan Indeks Glikemik Rendah. Prosiding Seminar Nasional Pangan Fungsional dalam Rangka Memperingati Hari Tempe Nasional. pp. 57-66.

Hidayat, Beni., Akmal, S., Muslihudin, M., Suhada, B., 2017. Assessment of Corn-Based Rice Analogues Made from Modified Corn Flour and Cassava Starch Which Processed by Granulation Method as Functional Food. Food Science and Quality Management, 61, pp.19-24.

Hidayat, B., 2016. Prospek Pengembangan dan Teknologi Pengolahan Beras Siger, UP Politeknik Negeri Lampung.

Homayouni, A. et al., 2014. Resistant starch in food industry : A changing outlook for consumer and producer. Starch/Stärke, 66, pp.102-114.

Hsu, R.J. et al., 2015. Effects of cooking, retrogradation and drying on starch digestibility in instant rice making. Journal of Cereal Science, 65, pp.154-161.

Lockyer, S. and \& Nugent, A.P., 2017. Health effects of resistant starch. Nutrition bulletin, 42(1), pp.10-41.

Lyumugabe, F.X., Tuyishime, M.A., Ntakirutimana, C., Harimana, Y. \& Hitabatuma, A., 2017. Latest Development Of Slowly Digestible Starch And Resistant Starch starch is. Journal of Multidisciplinary Engineering Science Studies (JMESS), 3(8), pp.2024-2037.

Raigond, P. et al., 2015. Resistant Starch in Food : A Review. Journal of the Science of Food and Agriculture, 95(10), pp.1968-1978.

Soekarto, S.T., 1985. Penilaian Organoleptik untuk Industri Pangan dan Hasil Pertanian, Jakarta: Penerbit Bhratara.

Zhao, X.H. and Lin, Y., 2009. The impact of coupled acid or pullulanase debranching on the formation of resistant starch from maize starch with autoclaving - cooling cycles. Eur. Food Res. Technol, 230, pp.179-184. 